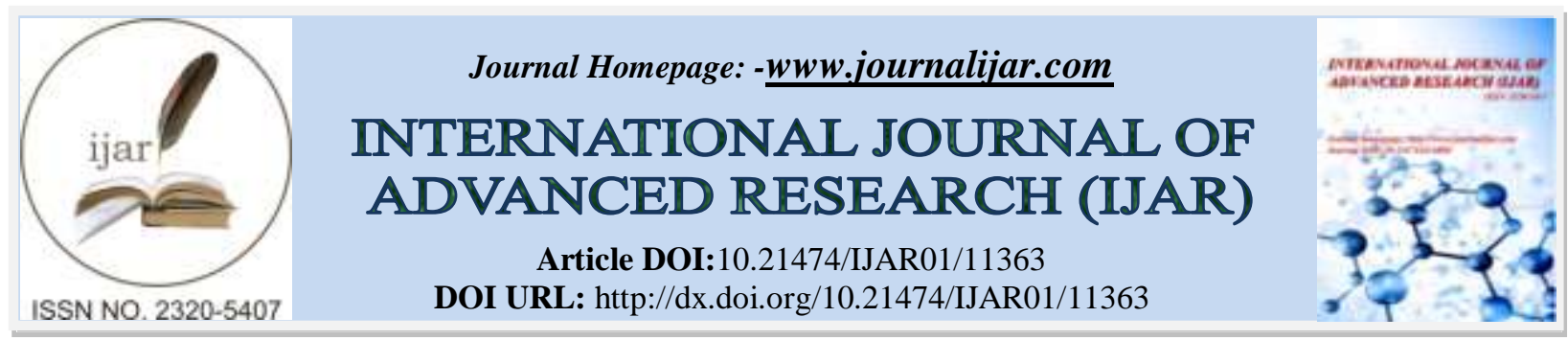

RESEARCH ARTICLE

\title{
NATIONAL RURAL HEALTH MISSION (NRHM) AND CHANGES IN MATERNAL AND CHILD HEALTH CARE: AN EVALUATIVE STUDY IN RAJASTHAN
}

\author{
Dr. G.S. Karol ${ }^{1}$ and Prof. B.K. Pattanaik ${ }^{2}$ \\ 1. Assistant Research Officer, National Institute of Health and Family Welfare, New Delhi-110067. \\ 2. Professor, School of Extension and Development Studies, IGNOU, New Delhi-110068.
}

\section{Manuscript Info}

…......................

Manuscript History

Received: 20 May 2020

Final Accepted: 24 June 2020

Published: July 2020

Key words:-

ANC, Delivery, PNC, Immunisation, TT, IFA, NRHM

\section{Abstract}

This study is based on the primary data collected from 160 households of 08 villages in Tonk district of Rajasthan. The main objective of the study was to find out the changes in four key basic health care services of MCH services- ANC, Delivery, PNC and Immunisation. The findings show that the percentage of ANC registration has gone up from 41.7 percent to 86.2 percent from the year 2006 to 2013. Similarly, the three ante-natal checkups, consumption of IFA and Vitamin-A tablets and administration of TT has gone up by 17.2, 66.7 and 23.2 percent respectively from 2006 to 2013 . It is important to note that 84.8 percent of antenatal women have received counselling on food and nutritional care during delivery which did not transpire before NRHM. The institutional delivery particularly in the government health care institutions has gone up by 37.1 percent. On the other hand, the percentage of home delivery has reduced by 49.4 percent. Thus NRHM has made a considerable difference in institutional delivery status. The status of post-natal care is very low and only 52.2 percent of women have received post-natal care checkup by ANM and only 42.1 percent post-natal women have received medicine/TT injection. This means a great deal of initiative has to be taken for raising the post-natal care of women. The full immunization status of children in the age-group 0-2 years has increased by 19.5 percent that is from 47.9 percent in 2006 to 67.4 percent in 2013. This means that population belonging to the rural areas has received more benefit through NRHM programme. In other words, NRHM has ensured equity in health care service distribution to the rural areas of backward districts as well as high focused state also.

Copy Right, IJAR, 2020,. All rights reserved.

\section{Introduction:-}

The SRS report 2015-2017 is encouraging to see the maternal mortality rate has fallen from 130 deaths per 100000 live births in 2014-2016 to 122 in 2015-2017. In the same period in MMR of Rajasthan state is 199 per 100,000 live births. This happen due to key government intervention such as the National Rural Health Mission (NRHM) in April, 2005, Janani Suraksha Yojna (JSY) in April, 2005 and Janani Sishu Suraksha Karyakaram JSSK in June,2011 scheme which made a concept push to increase access to quality maternal health services. Since 2005, coverage of essential maternal health services has doubled, while the proportion of institutional deliveries in public facilities has almost tripled, from $18 \%$ in 2005 to $52 \%$ in 2016 (including private facilities, institutional deliveries now stand at 
79\%). The state- subsidized demand-side financial like Janani Sishu Suraksha Karyakaram JSSK- which allows all pregnant women delivering in public health intuitions to free transport and no-expansive delivery. The government has put in substansive efforts to facilitate positive engagement between public and privete helath care providers. Campaigns such as the Pradhan Mantri Surakshit Matritva Abhiyan have been introduced with great impact, allowing women access to antenatal check-ups, obstetric gynecologists and to track high-risk pregnancies- exactly what is needed to make further gains and achieve the SDG targets.

The maternal health care $(\mathrm{MCH})$ comprises three important types of care: care during pregnancy called ante-natal care, care during delivery called natal-care and care after delivery known as post-natal care. Many maternal deaths take place in rural areas of Bihar, Uttar Pradesh, Odisha, Madhya Pradesh and Rajasthan because of poor access to quality maternal health care facilities in rural areas. One of the objectives of NRHM programme is to improve the $\mathrm{MCH}$ care and prevent maternal mortalities.

The Government of India and different state governments are striving hard to improve the health and well-being of their population. In April, 2005, the nation has launched National Rural Health

Mission in order to strengthen the delivery of primary health care services for the improvement of health status of rural population. The mission's major objectives include (i) Facilitating increased access and utilisation of quality health services by all; (ii) Reducing child and maternal mortality;(iii) Universalising access to public services for food and nutrition, sanitation and hygiene and to public health services with emphasis on services addressing women's and children's health and universal immunisation; (iv) Improving access to integrated comprehensive primary health care;(vi) Seeing a concomitant reduction in infant mortality rate (IMR), maternal mortality rate (MMR) and total fertility rate (TFR).

Prasad et al. (2013), in their paper "Addressing the Social Determinants of Health through Health System Strengthening and Inter-Sectoral Convergence: The Case of the Indian National Rural Health Mission", have noted that at the turn of the 21st century, India was plagued by significant rural-urban, inter-state and inter-district inequities in health. For example, in 2004, the infant mortality rate (IMR) was 24 points higher in rural areas compared to urban areas. To address these inequities, to strengthen the rural health system (a major determinant of health in itself) and to facilitate action on other determinants of health, India launched the National Rural Health Mission (NRHM) in April 2005. Under the NRHM, Rs. 666 billion (US\$12.1 billion) was invested in rural areas from April 2005 to March 2012. There was also a substantially higher allocation for 18 high-focus states and 264 high-focus districts, identified on the basis of poor health and demographic indicators. Other determinants of health, especially nutrition and decentralized action, were addressed through mechanisms like State/District Health Missions, Village Health, Sanitation and Nutrition Committees, and Village Health and Nutrition Days. As a result, in bigger high focus states, rural IMR fell by 15.6 points between 2004 and 2011, compared to 9 points in urban areas. Similarly, the maternal mortality rate in high-focus states declined by 17.9 percent between 2004-2006 and 2007-2009 compared to 14.6 percent in other states.

Thimmaiah and Mamatha (2014) conducted a study on "National Rural Health Mission and Rural Health Status in Karanataka: An Economic Analysis". The main objective was to study the impact of NRHM in terms of health infrastructure and to examine the impact of NRHM on health indicators, like IMR, MMR, CDR and TFR in Karnataka. The study result shows that the number of Sub Centers, Primary Health Centres and Community Health Centres increased between 2005 and 2010. Also IMR, MMR, CDR and TFR have come down after the implementation of National Rural Health Mission.

\section{Objectives:-}

1. To study the changes in MCH Services (ANC, Delivery, PNC and Immunisation) status of the women's of Rajasthan.

2. To assess the impact of NRHM on child immunization of 0-2 years of children.

3. To study the impact of NRHM on Infant and maternal mortality rate.

\section{Methodology:-}

The study is based on the primary data collected from more than 160 households of 08 villages in Tonk district of Rajasthan, the Tonk district is a less advanced district. The one advance and one backward PHC were selected from the block. The villages were selected randomly from the list of villages available in the block. The primary data of 
district Tonk is comparison from secondary data gathered from the various sources like; NHFS-4, DLHS-3 of state Rajasthan.

\section{Discussion:-}

\section{Maternal Health Care:}

The maternal health care $(\mathrm{MCH})$ comprises three important types of care: care during pregnancy called ante-natal care, care during delivery called natal-care and care after delivery known as post-natal care. Many maternal deaths take place in rural areas of Bihar, Uttar Pradesh, Odisha, Madhya Pradesh and Rajasthan because of poor access to quality maternal health care facilities in rural areas. One of the objectives of NRHM programme is to improve the $\mathrm{MCH}$ care and prevent maternal mortalities. Tables-1.1 \& Fig.-1.1 describe the status of ante-natal, natal and postnatal care.

Table 1:- Ante-Natal Care Status of Women before and After NRHM in Tonk District and Rajasthan, 2013.

\begin{tabular}{|c|c|c|c|c|c|c|c|}
\hline \multirow{2}{*}{$\begin{array}{l}\text { S. } \\
\text { No. }\end{array}$} & \multirow[t]{2}{*}{ ANC } & \multicolumn{3}{|l|}{ Tonk } & \multicolumn{3}{|c|}{ Rajasthan } \\
\hline & & 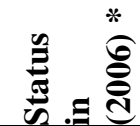 & 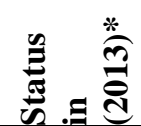 & 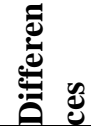 & 总 & 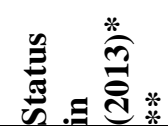 & : \\
\hline 1. & $\begin{array}{l}\begin{array}{l}\text { Percentage } \\
\text { registration }\end{array} \\
\text { of } \quad \text { ANC }\end{array}$ & 49.5 & 89.4 & 39.9 & 34.0 & 83.0 & 49.0 \\
\hline 2. & $\begin{array}{l}\text { Percentage of three ante- } \\
\text { natal check ups }\end{array}$ & 38.9 & 58.1 & 19.2 & 23.4 & 38.5 & 15.1 \\
\hline 3. & $\begin{array}{l}\text { Percentage of ante-natal } \\
\text { women received IFA and } \\
\text { Vitamin-A Tablets }\end{array}$ & 37.4 & 83.8 & 46.4 & 53.5 & 92.3 & 38.8 \\
\hline 4. & $\begin{array}{l}\text { Percentage of ante-natal } \\
\text { women received } \mathrm{T} \mathrm{T}-2\end{array}$ & 71.6 & 81.9 & 10.3 & 53.7 & 89.7 & 36.0 \\
\hline 5. & $\begin{array}{l}\text { Percentage of ante-natal } \\
\text { women given counselling } \\
\text { on food and nutrition }\end{array}$ & NA & 80.0 & NA & NA & 89.7 & NA \\
\hline
\end{tabular}

Note: * DLHS-3 (2007-08) data of Rajasthan. **Field Survey data conducted during 2013. ***NFHS-4(2015-16)

Table1.1:- Ante-Natal Care Status of Women before and After NRHM in Tonk District and Rajasthan, 2013 (In Percentage).

\begin{tabular}{|l|l|l|l|l|}
\hline S. & ANC & Tonk and Rajasthan & Difference \\
\cline { 3 - 4 } & $\begin{array}{l}\text { Status in } \\
(\mathbf{2 0 0 6})^{*}\end{array}$ & Status in (2013)** & \\
\hline 1. & Percentage of ANC registration & 41.7 & 86.2 & 44.5 \\
\hline 2. & $\begin{array}{l}\text { Percentage of three ante-natal check } \\
\text { ups }\end{array}$ & 31.1 & 48.3 & 17.2 \\
\hline 3. & $\begin{array}{l}\text { Percentage of ante-natal women } \\
\text { received IFA and Vitamin-A Tablets }\end{array}$ & 45.4 & 88.1 & 66.7 \\
\hline 4. & $\begin{array}{l}\text { Percentage of ante-natal women } \\
\text { received T T-2 }\end{array}$ & 62.6 & 85.8 & 23.2 \\
\hline 5. & $\begin{array}{l}\text { Percentage of ante-natal women given } \\
\text { counseling on food and nutrition }\end{array}$ & NA & 84.8 & NA \\
\hline
\end{tabular}

Note: * DLHS-3 (2007-08) data of Rajasthan. **Field Survey data conducted during 2013. ***NFHS-4(2015-16) 


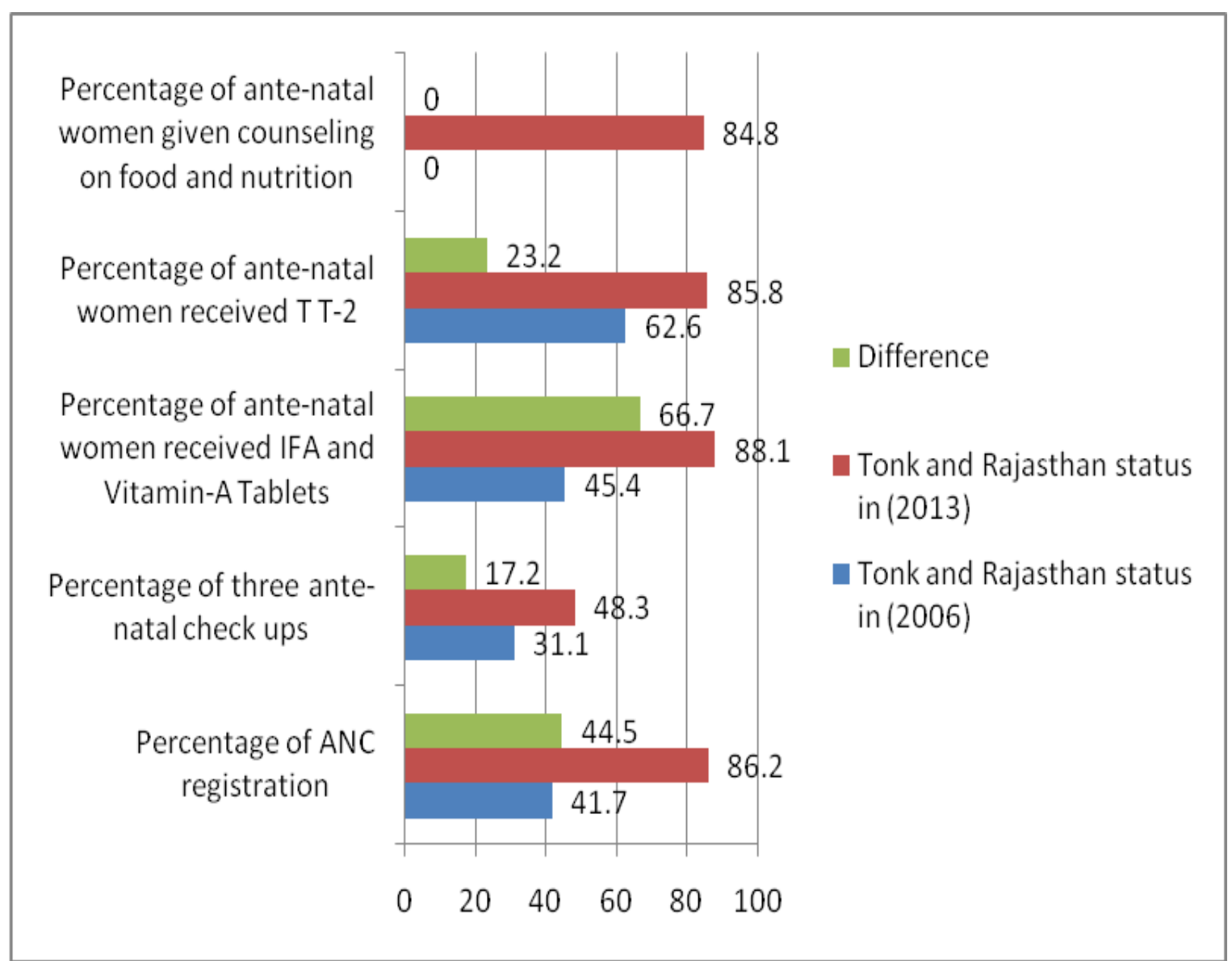

Fig.1:- Ante-Natal Care Status of Women before and After NRHM in Tonk District and Rajasthan, 2013.

Table-1 shows that the change percentage of women who have received ANC care, regular checkup, consumption of IFA, Vitamin-tablets, administration of TT injection and counselling about food nutrition difference is $39.9,19.2$, $46.4,10.3$ and in case of Rajasthan state is $49.0,15.1,38.8$, and 36.0 percent respectively.

\section{NRHM and Natal Care (Delivery):}

Giving birth is a life changing event for women. The care that a woman receives during delivery (labour) has the potential to affect her in the short and long term both physically and emotionally, and the health of her baby. Good communication, support and compassion from family and health welfare staff, and having her wishes respected, can help her feel in control of what is happening and contribute to making birth a positive experience for her and her birth companion(s). One of the goals of NRHM is the reduction of Infant Mortality Rate (IMR) and Maternal Mortality Rate (MMR) which depends on the care of mother and child during the delivery. The natal health care status of eligible women of the two districts is shown in Tables -1.2, 1.3 \& Fig.-1.2

Table 1.2:- Natal Care (Delivery) Status Before and After NRHM in Tonk District and Rajasthan, 2013.

\begin{tabular}{|l|l|l|l|l|l|l|l|}
\hline \multirow{2}{*}{$\begin{array}{l}\text { S. } \\
\text { No. }\end{array}$} & Delivery & \multicolumn{2}{|l|}{ Tonk } & \multicolumn{2}{l|}{ Rajasthan } \\
\cline { 2 - 8 } & Delivery & $\begin{array}{l}\text { Status } \\
\text { in } \\
\mathbf{( 2 0 0 6 ) *}\end{array}$ & $\begin{array}{l}\text { Status in } \\
\mathbf{( 2 0 1 3 ) * *}\end{array}$ & Differences & $\begin{array}{l}\text { Status } \\
\text { in } \\
\mathbf{( 2 0 0 6 ) *}\end{array}$ & Status in (2013)**** & Differences \\
\hline 1. & Government & 47.5 & 81.9 & 34.4 & 42.5 & 80.1 & 37.6 \\
\hline 2. & Private & 1.2 & 15.6 & 14.4 & 4.2 & 16.6 & 12.4 \\
\hline 3. & Home & 51.3 & 2.5 & 48.8 & 53.3 & 3.3 & 50.0 \\
\hline
\end{tabular}

Note: * DLHS-3 (2007-08) data of Rajasthan. **Field Survey data conducted during 2013. ***.NFHS4-(15-16) 
Table1.3:- Natal Care (Delivery) Status Before and After NRHM in Tonk District and Rajasthan, 2013 (In Percentage).

\begin{tabular}{|l|l|l|l|l|}
\hline \multirow{2}{*}{$\begin{array}{l}\text { Sl. } \\
\text { No. }\end{array}$} & \multirow{2}{*}{ Delivery } & \multicolumn{3}{|c|}{ Tonk and Rajasthan } \\
\cline { 3 - 5 } & & Status in (2006)* & Status in (2013)** & Differences \\
\hline 1. & Government & 45.0 & 81.0 & 37.1 \\
\hline 2. & Private & 2.7 & 16.1 & 13.4 \\
\hline 3. & Home & 52.3 & 2.9 & 49.4 \\
\hline
\end{tabular}

Note: * DLHS-3 (2007-08) data of Rajasthan. **Field Survey data conducted during 2013. ***NFHS-4(15-16)

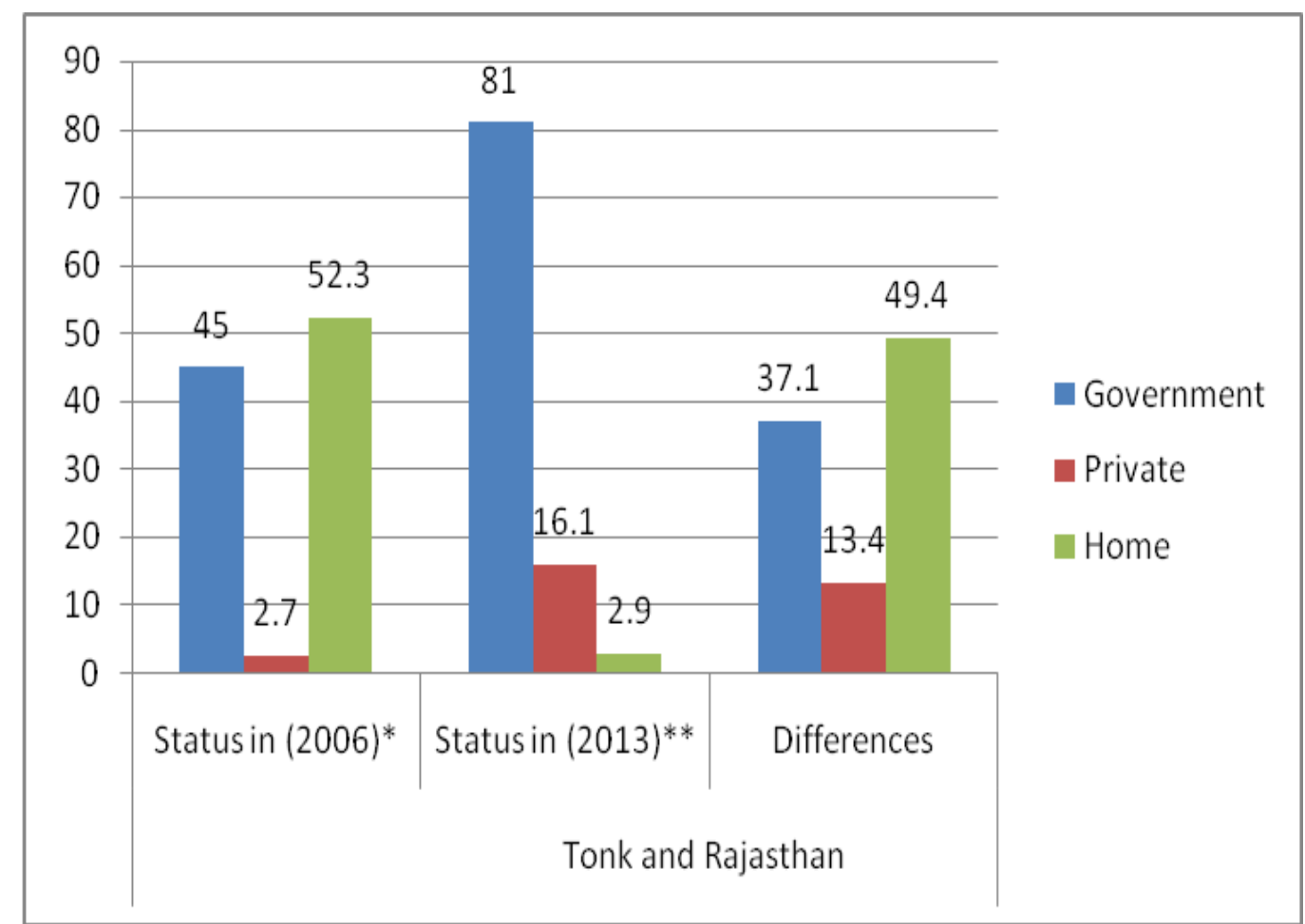

Fig.-1.2:- Natal Care (Delivery) Status Before and After NRHM in Tonk District and Rajasthan, 2013

(In Percentage).

Table-1.3 \& Fig.-1.2 reveals that institutional delivery has improved after the implementation of NRHM by 37.1 and 13.4 percent in case of government and private hospitals respectively. And the home deliveries have been reduced by 49.4 percent. The analysis of data in table 1.3 shows that the Tonk district and state Rajasthan have gained more or less equally from the launch of NRHM. The gap in performance between the state and backward district has reduced and backward district Tonk has performed better than the state to reduce home deliveries. Thus, NRHM has a positive effect on natal care. Table-1.2 in Rajasthan state institutional deliveries has improved after the implementation of NRHM by 37.6 and 12.4 percent in case of government and private hospitals respectively. And the home deliveries have been reduced by 50.0 percent. There are drastic changes in reducing of home deliveries and save the lives of the mothers in high focused state of Rajasthan.

NRHM and Post-Natal Care:

The status of post-natal care received by lactating women is shown in Table-1.4

Table 1.4:- Post-Natal Care Services NRHM in Tonk District and Rajasthan, 2013(in percentage).

\begin{tabular}{|c|c|c|c|c|}
\hline \multirow{2}{*}{$\begin{array}{l}\text { Sl. } \\
\text { No. }\end{array}$} & PNC Services & Tonk & Rajasthan & Total \\
\hline & PNC Services & $\begin{array}{l}\text { Status in } \\
(\mathbf{2 0 1 3}) *\end{array}$ & $\begin{array}{l}\text { Status in } \\
(\mathbf{2 0 1 3}) * *\end{array}$ & $\begin{array}{l}\text { Tonk and Rajasthan } \\
\text { (In Percent) } 2013\end{array}$ \\
\hline 1. & $\begin{array}{l}\text { Percent of Post Natal Care services- Checkup by } \\
\text { ANM }\end{array}$ & 43.1 & 61.5 & 52.3 \\
\hline
\end{tabular}




\begin{tabular}{|l|l|l|l|l|}
\hline 2. & $\begin{array}{l}\text { Percent of Post Natal Care services - At least } \\
\text { one checkup by MO/ Qualified doctor }\end{array}$ & 63.7 & 38.7 \\
\hline 3. & $\begin{array}{l}\text { Percent of Post -Natal women received } \\
\text { Medicine/ Injection- TT }\end{array}$ & 20.6 & 63.7 & 42.1 \\
\hline 4. & $\begin{array}{l}\text { Percent of Post -Natal women given } \\
\text { counselling on food and Nutrition }\end{array}$ & $\begin{array}{l}\text { Pen } \\
\text { counselling on New born care (Breast feeding) }\end{array}$ & 92.3 & 82.1 \\
\hline 5. & \begin{tabular}{l} 
Percent of Post -Natal women given \\
\hline
\end{tabular}
\end{tabular}

* Field Survey data conducted during 2013. **NFHS-4(15-16)

Table-1.4 shows various post-natal care such as PNC- regular checkup by ANM, one checkup by MO, administered medicine/injection-TT, counselling on food and nutrition and counselling on child care (breast feeding) after the implementation of the NRHM by 43.1, 13.8, 20.6, 71.9 and 74.4 percent for Tonk District and 61.5, 63.7, 63.7, 92.3 and 92.3 percent for Rajasthan state respectively. The data also shows that in Tonk District the percentage of PNC women who have been given counselling about food and nutritional care and child care is lower than Rajasthan figure. The analysis of data in Table-1.4 shows that the lagged district has gained from the launch of NRHM less as compare to the state.

\section{NRHM and Child Immunisation:}

Immunisation of children against preventive diseases is an essential component of child health care. Although, through various health care programme interventions, the immunisation status of children is improving, yet the status of immunization in children in rural areas is still low, particularly in the health laggard states. A great deal of endeavour is required to raise the immunisation status of children especially in 0-2 year's age group to check infant mortality.Table-1.5 presents an analysis of immunisation status of children in 0-2 years.

Table 1.5:- Immunisation Status of Children (0-2) Years Age Group before and After NRHM in Tonk District and Rajasthan (In Percentage).

\begin{tabular}{|l|l|l|l|l|l|l|l|}
\hline $\begin{array}{l}\text { S. } \\
\text { No. }\end{array}$ & $\begin{array}{l}\text { Child } \\
\text { Imunisation }\end{array}$ & \multicolumn{2}{|l|}{ Tonk } & \multicolumn{2}{l|}{ Rajasthan } \\
\hline & $\begin{array}{l}\text { Child } \\
\text { Immunisation } \\
(\mathbf{0 - 2} \text { years) }\end{array}$ & $\begin{array}{l}\text { Status in } \\
(\mathbf{2 0 0 6})^{*}\end{array}$ & $\begin{array}{l}\text { Status in } \\
(\mathbf{2 0 1 3})^{* *}\end{array}$ & Differences & $\begin{array}{l}\text { Status in } \\
(\mathbf{2 0 0 6})^{*}\end{array}$ & $\begin{array}{l}\text { Status in } \\
(\mathbf{2 0 1 3})^{* * *}\end{array}$ & Differences \\
\hline $\mathbf{1 .}$ & $\begin{array}{l}\text { Full } \\
\text { immunisation }\end{array}$ & 46.8 & 78.8 & 32.0 & 49.0 & 56.0 & 7.0 \\
\hline $\mathbf{2 .}$ & $\begin{array}{l}\text { Partial } \\
\text { immunisation }\end{array}$ & 50.4 & 20.4 & 30.0 & 38.9 & 35.2 & 3.7 \\
\hline 3. & No immunisation & 3.0 & 0.8 & 2.2 & 12.1 & 8.8 & 3.3 \\
\hline
\end{tabular}

Note: * DLHS-3 (2007-08) data of Rajasthan. **Field Survey data conducted during 2013. ***NFHS-4(2015-16)

Table 1.6:- Immunisation Status of (0-2) Years Children Before and After NRHM in Tonk District and Rajasthan (In Percentage).

\begin{tabular}{|l|l|l|l|l|}
\hline \multirow{2}{*}{$\begin{array}{l}\text { S. } \\
\text { No. }\end{array}$} & Child Immunistion & Tonk and Rajasthan & $\begin{array}{l}\text { Tonk } \\
\text { Rajasthan }\end{array}$ & and \\
\cline { 2 - 5 } & $\begin{array}{l}\text { Child Immunisation(average) } \\
(\mathbf{0 - 2} \text { years) }\end{array}$ & Status in (2006)* & Status in (2013)** & Difference \\
\hline 1. & Full immunisation & 47.9 & 67.4 & 19.5 \\
\hline 2. & Partial immunisation & 44.6 & 27.8 & 16.8 \\
\hline 3. & No immunisation & 7.5 & 4.8 & 2.7 \\
\hline
\end{tabular}

Note: * DLHS-3 (2007-08) data of Rajasthan. $\quad * *$ Field Survey data conducted during 2013. ***NFHS-4(2015-16) 


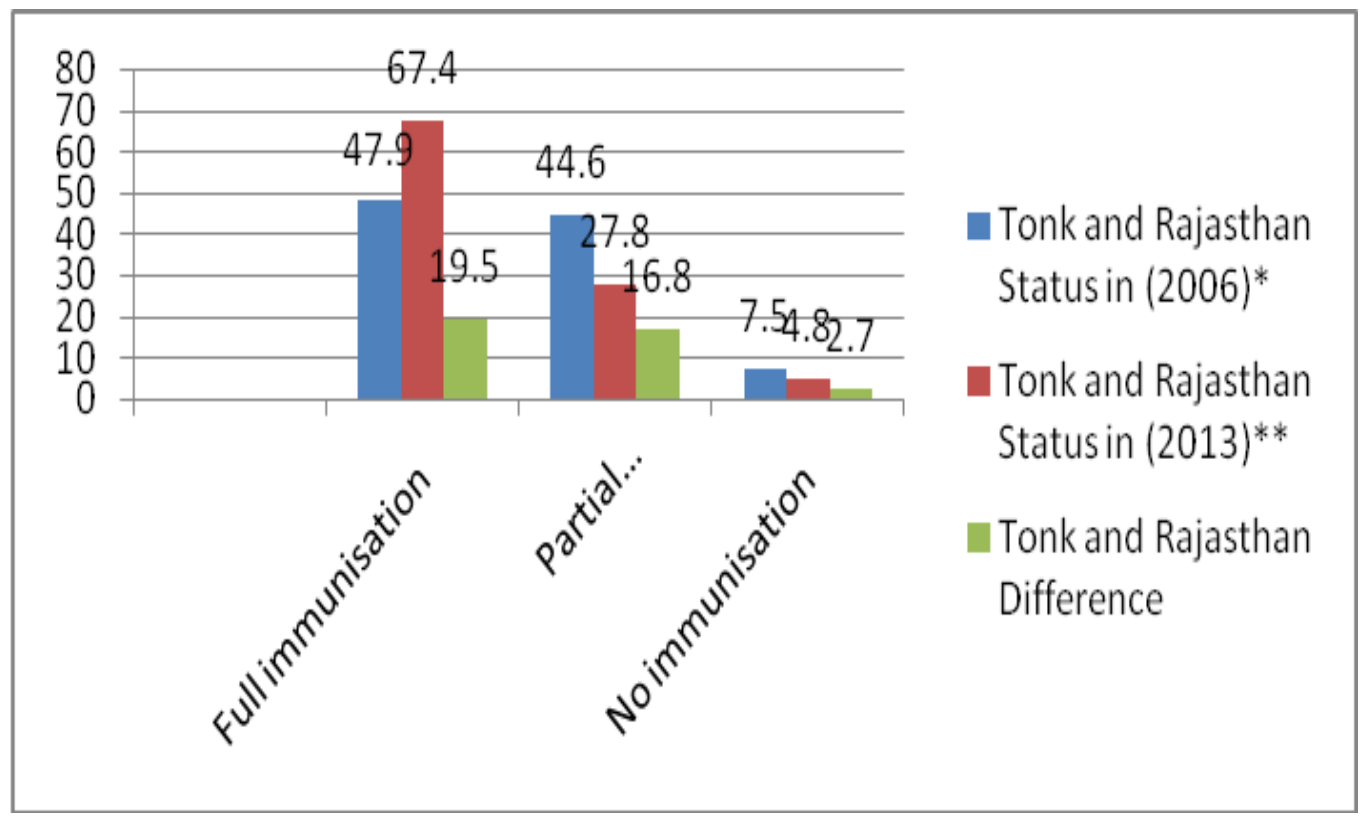

Fig.-1.3:- Immunisation Status of (0-2) Years Children Before and After NRHM in Jaipur and Tonk Districts.

Table-1.6 shows full, partial and no immunisation status of children's of 0-2 years after the implementation of the NRHM by $67.4,27.8, \& 4.8$ percent for Tonk District and Rajasthan respectively. The data also shows that percent change from year 2006 to 2013 in Tonk and Rajasthan full, partial and no immunisation status children's is 19.5, 16.8 and 2.7 percent respectively.

Infant and Maternal Mortality Status:

Table-1.7 accounts the infant and maternal deaths in the two districts.

Table-1.7:- Infant and Maternal Mortality Status.

\begin{tabular}{|l|l|l|l|}
\hline $\begin{array}{l}\text { Sl. } \\
\text { No }\end{array}$ & IMR/MMR during in the last 1 year & Tonk & Rajasthan \\
\cline { 3 - 4 } & & Current status (2013) $* *$ & Current status (2013) $* *$ \\
\hline 1. & Maternal Mortality Rate (MMR) & 223 & 208 \\
\hline 2. & Infant Mortality Rate (IMR) & 66 & 59 \\
\hline
\end{tabular}

Note: *Field Survey data conducted during 2013. **AHS-2012-13 Rajasthan

Table-1.7 shows that in the Tonk district maternal mortality is high than the state, 223 women's in Tonk district and 208 women's in Rajasthan state died as a consequence of delivery. However, infant mortality is a cause of concern as the IMR is 66 and 59 in Tonk and Rajasthan respectively. Rajasthan has improved significantly on its maternal and child survival indicators in the last 10 years between 2005-06 and 2015-16.

The main reasons for the death of children in the Tonk districts, lack of ANC, medical negligence, observance of traditional faiths, and lack of health education, lack of food and nutrition and unknown causes of death. In over all Rajasthan most reasons for the death of children are prematurity or low birth weight, neonatal infections, and birth asphyxia or trauma. Most of the Infant Mortality Rates (IMR) is caused by low birth weight.

\section{Conclusion:-}

After implementation of NRHM, the antenatal care status of women has improved. The percentage of ANC registration in Tonk District and Rajasthan has gone up from 41.7 percent to 86.2 percent from the year 2006 to 2013.

The three ante-natal checkups, consumption of IFA and Vitamin-A tablets and administration of TT has gone up from 31.1 to $48.3,45.4$ to 88.1 and 62.6 to 85.8 percent respectively from year 2006 to 2013 . It is important to note 
that 80.0 percent in Tonk district and in Rajasthan state 89.7 of antenatal women have received counselling on food and nutritional care during delivery which did not transpire before NRHM.

The institutional delivery particularly in the government health care institutions has gone up by 34.4 percent in Tonk District and over all state of Rajasthan gone up by 37.6 percent. On the other hand, the percentage of home delivery has reduced by 48.8 percent and 50.0 percent respectively. Thus NRHM has made a considerable difference in institutional delivery status.

The status of post-natal care is very low and only 43.1 percent of women have received post-natal care checkup by ANM and only 20.6 percent post-natal women have received medicine/TT injection. In the state figure shows that 61.5 percent of women have received post-natal care checkup by ANM and 63.7 percent post-natal women have received medicine/TT injection. This means a great deal of initiative has to be taken for raising the post-natal care of women in the Tonk district as compare to the state.

The full immunization status of children in the age-group 0-2 years has increased by 32.0 percent that is from 46.8 percent in 2006 to 78.8 percent in year 2013. And same period in the state 7.0 percent that is 49.0 percent in year 2006 to 56.0 percent in 2013. This shows that NRHM has produced positive impact on immunization of children. The more infant deaths occur as a result of observance of traditional faiths and beliefs in the backward district. In Rajasthan most reasons for the death of children are prematurity or low birth weight, neonatal infections, and birth asphyxia or trauma in the state. Most of the Infant Mortality Rates (IMR) is caused by low birth weight.

\section{References:-}

1. SRS Bulletin 2019

2. https://www.who.int/southeastasia/news/detail/10-06-2018-india-has-achieved-groundbreaking-success-inreducing-maternal-mortality

3. Field survey data conducted during 2013.

4. DLHS-3 (2007-08) data of Rajasthan

5. NFHS- 4(2015-16) data of Rajasthan

6. SRS- (2014-2015)

7. Thimmaiah, N., and K. G. Mamatha. 2014: "National Rural Health Mission and Rural Health Status in Karnataka: An Economic Analysis", PARIPEX-Indian Journal of Research, Vol 3, Issue 5, 44-47.

8. Prasad, A. M., G. Chakraborty, S. S. Yadav and S. Bhatia. 2013: "Addressing the social determinants of health through health system strengthening and inter-sectoral convergence: the case of the Indian National Rural Health Mission" Global Health Action, March 6: 2013. 